\title{
THE RISK OF EXCLUDING PEOPLE WITH SENSORY DISABILITIES FROM EDUCATION AS A CONSEQUENCE OF THE COVID-19 PANDEMIC
}

\begin{abstract}
The authors refer to the risk of people with sensory disabilities dropping out of higher education in Poland due to the move towards online learning during the COVID-19 pandemic. They present information on the unique situation of students with sensory dysfunctions, refer to the issues of distance learning in higher education, and present the methodological assumptions behind their research. The outcome of the research and observations resulting from the authors' practical experiences allowed them to formulate conclusions that relate to various areas of distance learning, including technology and methodology, the social-psychological area, the need for equipment, the evaluation of distance education and its negative vs positive aspects. This allowed them to reveal certain aspects of online learning of people with disabilities associated with the need to further explore the issues raised in theoretical, empirical, and practical dimensions.
\end{abstract}

Keywords: students, sensory disability, online education, COVID-19 pandemic

Dr, Faculty of Educational Sciences, Department of Andragogy and Social Gerontology; e-mail: anna.gutowska@now.uni.lodz.pl; https://orcid.org/0000-0001-5258-8772

Dr, Faculty of Economics and Sociology, Department of Applied Sociology and Social Work; e-mail: joanna.giercuszkiewicz@eksoc.uni.lodz.pl; https://orcid.org/0000-0002-2148-4345 


\section{INTRODUCTION}

In recent years, there has been a significant increase in the participation of people with disabilities in academic education in Poland - from 9,247 in 2004 to 21,249 in 2019 [GUS - Statistics Poland 2005, 2020]. It was undoubtedly caused not only by changes in society's mentality, including people with disabilities themselves and their parents, but also by the increasingly common practice of enrolling children with disabilities in mainstream schools. These indicators also reflect the general, intense increase in social interest in higher education ${ }^{1}$ and creating new legal frameworks for studies of people with disabilities and the resulting institutional changes in higher education in Poland ${ }^{2}$. Nevertheless, students with disabilities still make only a tiny percentage of the overallnumber of Polish students (e.g., in the Netherlands, France, Lithuania, Ireland, Denmark and Austria, which are the European leaders in this respect, the percentage ranges from 6 to 13\% [Hauschildt, Gwosć, Netz, Mishra 2015], which is not an impressive result ${ }^{3}$ ).

The group that stands out from the general category of students with disabilities are people with sensory organ dysfunctions, i.e., hearing and vision. According to GUS reports, in 2019, deaf and hard-of-hearing students accounted for $7.5 \%$ of all students with disabilities, while those who were blind and visually impaired accounted for $8.5 \%$ [GUS 2020]. These two groups of students (incidentally very heterogeneous in their specifics and the severity of dysfunction), also have exceptional needs in terms of access to the didactic process, including learning materials, communication, but also electronic media [cf. Rzepka 2007, Domagała-Zyśk 2013].

The functioning of people who are deaf and hard-of-hearing in higher education is determined by factors such as the degree of hearing loss, the time of dysfunction development (e.g., the pre-, peri- or post-lingual period), the availability of rehabilitation equipment and hearing prostheses (e.g., cochlear implants, hearing aids), the preferred way of communicating (e.g., using sign language, writing, or lip-reading), or the use of assisting technologies (e.g., speech-to-text)

1 Between 1990 and 2006, the scholarization rate for higher education in Poland increased from $13 \%$ to almost $50 \%$ [Garbat 2006, GUS 2007].

2 Changes in the Law on Higher Educationin Poland between 2005 and 2019 introduced a number of provisions to equalise the educational opportunities for people with disabilities.

3 The numbers refer only to those with a legally recognised disability, i.e., with disability certificates. GUS does not keep statistics on the share in higher education of biologically disabled people (i.e., those who have no disability certificates, and who experience, as a result of impaired ability, barriers in their contact with the physical and social environment, in accordance with the definition in the Convention on the Rights of Persons with Disabilities [2012]). 
[Muller-Siekierska 2019, Krakowiak 2013, Domagała-Zyśk 2013]. Thus, the notion of "hearing impairment" is very broad, with a wide spectrum of consequences for education.

The support of information and communication technologies is one of the basic tools used in the education and rehabilitation of people with hearing impairments [Błeszyński 2006]. As noticed by Domagała-Zyśk [2013: 18], the real revolution in the communication of people with hearing impairment was caused by the Internet, mobile phones, and other devices, such as smartphones and tablets, because they facilitate independent and mobile communication with the use of writing. Thus, in light of the above, it might reasonably be assumed that the Covid-19 pandemic and the transfer of higher education to distance learning should have no negative consequences for this group of students, which seems to be confirmed by earlier research on deaf people following their studies with the use of e-learning [Richardson, Long, Woodley 2004].

The group of people with visual disabilities is very heterogeneous. The classification of this dysfunction includes people who are blind from birth (with no sense of light), those who lost their eyesight after five years of age (which allows them to maintain visual images in their memory), those with poor vision or those who are losing their vision [Klyszcz 2007, Czerwińska 2016]. It is also significant for the education process if, as a child, a person with visual impairment attended a mainstream school or a special education training centre, or if a person uses Braille ${ }^{4}$ [Rzepka 2007]. Applying techniques that compensate for sensory losses in eyesight based on the use of other senses (i.e., hearing and touch) allows visually impaired young people to achieve their educational goals. In higher education, the learning materials and the education process should also be adapted to the needs of people who are blind or visually impaired, while e-learning systems and distance learning digital platforms should be tailored to the characteristics of this group.

\section{Distance learning in higher education}

Contemporary students grew up in an environment that is totally different from that of earlier generations. They were brought up by the Internet, they know no life without it, and the virtual world is their point of reference. They are included

4 In recent times, the skill of using Braille (dot writing) is fading among people with visual impairment. According to the estimations by the "Chance for the Blind" Foundation, only 10\% of blind people use the system. It is associated with the increasing trend to send blind children to mainstream schools and with the increasingly common use of digital technologies, offering visually impaired people access to almost unlimited resources [Czerwińska 2014]. 
among the so-called "digital natives" [Sajduk 2015], perfectly acquainted with computers, tablets, smartphones, etc. Despite this, many of them had never experienced formal distance education before the pandemic.

2020 turned out to be the turning point for distance learning. The Covid-19 pandemic forced educational institutions to shift towards distance education almost immediately. Suddenly, in most cases, without profound knowledge, skills, methods or tools, both teachers and students had to start performing their tasks online. The rate of this unprecedented acceleration was incredibly fast, taking only a few months to carry it out.

Distance learning has existed for a long time, ${ }^{5}$ but before the pandemic, at many Polish universities, it was treated more as an extra addition to learning and not as the major trend in education. Few academic teachers, enthusiasts of using new technologies or educational platforms in their teaching, were interested in distance learning. Also, the regulations in force ${ }^{6}$ did not allow programmes to be launched that were offered completely online. This kind of education was perceived with distrust and reserve. Today, distance learning, most often called e-learning, is widely known and used.

Wierzbicka defines e-learning as a complex educational process, planned institutionally, that leads to the intended activity of all education participants (i.e., those who learn and the teachers), responds to the needs and abilities of the learning community, inspires people to act and achieve educational goals, and that makes it possible to run cognitive and emotional education discourse using electronic media (computers, tablets, smartphones, and the Internet, among other) [Wierzbicka 2019: 16-17].

Thus, it can be assumed that e-learning stands for education using electronic media. The process involves specially designed tools, including education platforms, computer applications, websites, email, discussion forums, messaging systems, videoconferences, or more complex technological systems. Important elements of the process include provision for the abilities and needs of learners as well as for the social distance, which means that the effectiveness of e-learning depends on numerous factors. The advantages of e-learning are commonly said to include being able to effectively teach many learners at the

5 The main objective of introducing distance learning in academic centres was to allow students to obtain an education regardless of their origin, age, sex, socio-economic environment, views, family circumstances, or health [Mechlińska-Pauli 2000: 125].

6 In Polish higher education, it was the Law on Higher Education of 27 July 2005 that sanctioned classes for higher education students using distance learning methods and techniques [art. 164 p. 3]. 
same time, and being able to learn in any place, at any time and at one's own pace. This allows courses to be completed without being physically present in a lecture hall. Critics of modern technologies in higher education are numerous, citing the technologisation of yet another sphere of human life and a decrease in the effectiveness and quality of studies.

The literature on the subject contains statements that introducing modern technologies into lecture halls and classrooms should not be an end in itself but an element that supports the education process. Technology should help its users increase the effectiveness and comfort of learning. Undoubtedly, well prepared and efficiently run e-learning classes, offered using the latest advances in distance learning, with a possibility of voice interaction and a webcam, can be effective and efficient.

E-learning includes six interconnected areas that influence each other [Plebańska 2011: 11-12]:

1. Content - electronic education materials shared with students (texts, e-books, internet publications, audiobooks, illustrations, animations, simulations, games, e-tests, e-exercises, videoconferences, podcasts, webcasts, etc.).

2. Technology - different types of software and hardware, i.e., the technological infrastructure.

3. Context - the conditions in which courses are implemented, with particular attention paid to the scale (including the number of users), duration, substantive scope, characteristics of the target group, and the specific character of the content).

4. People - the target group of users, characterised from the angle of experience in distance learning/teaching, competencies in information technology, and attitudes to e-learning, among others).

5. Communication - the way, form and rules of e-learning regarding the various layers (student - teacher, student - student).

6. Behaviours - determining different types of psycho-social behaviours that take place during classes, associated with perceiving, understanding and sensing.

The enumerated areas interact and influence one another, although e-learning should only take place when all of them are taken into consideration. Hence, the education process requires that institutions prepare resources that, according to Wierzbicka, include funds (to cover personnel costs, costs of equipment, training, rooms, etc.), human resources (specialists in subject, methodology, and administration), information resources (internal and external) and material resources (hardware, software, multimedia library, etc.) [Wierzbicka 2019: 22]. 
A university that implements e-learning should know the options in particular areas and secure tangible and intangible assets. Still, human resources seem to be the key element. At this point, one should ask to what extent universities were prepared to introduce distance learning. The question appears rhetorical because one can guess that no institution was prepared. Hence, it is difficult to assume that the e-learning that has been present in higher education for the last few months fulfilled the criteria attributed to this form of education. The consequences are reflected in the quality of studying.

For students with sensory disorders, it is necessary to adjust the education process, including appropriately adapting education materials to their needs and abilities. In addition to the rules necessary for e-learning, it is indispensable to consider the characteristics of this group of students. Otherwise, universities risk their students failing to achieve learning outcomes, but also the students being excluded from education altogether.

\section{METHODOLOGY}

The motivation to research the topic of students with disabilities dropping out from the education system was derived from the observations and direct experiences of the authors in their work as rector's plenipotentiaries for students with disabilities at the two largest academic centres in Lodz: the University of Lodz and Lodz University of Technology. After universities switched fully to distance learning in March 2020, some students with disabilities started "disappearing" from virtual education spaces - not only did they stop attending classes, but they also could not be reached by the university staff (teachers, the dean's office staff or officers who deal with student support and welfare). This phenomenon, although of a global character (some students without disabilities also stopped showing up for class and abandoned their studies), intensified and, as it turned out, in a different context - in the case of students with disabilities. The groups that were most vulnerable to exclusion from distance education included people with sensory disabilities (i.e., visual and hearing) and people with mental disorders and pervasive development disorders (e.g., Asperger's syndrome). Due to the extensive material and varied specifics of distance education for these two groups with disabilities, the article concentrates on students with hearing dysfunctions (hard-of-hearing, deaf) and visual dysfunctions (visually impaired, blind).

The research was exploratory and was designed within the trend of "hot sociology", understood as an attempt to get a hold of testimonials and 
understand the mechanisms for social changes at the moment of their occurrence [Szacka 2003, Męcfal, Surmiak, Ślęzak 2020]. The basic objective of the analyses performed between May and late September 2020 was to identify problems associated with distance education of students and doctoral students with various types of disabilities during the Covid-19 pandemic. The outcome of the research is a description of the education process at Polish universities for students with disabilities during the coronavirus pandemic. The research also provides diagnostics that consider factors that determine the education of people with various types of disabilities via the Internet.

For the research, an anonymous survey was carried out among 291 students and doctoral students with disabilities, age 19-56, from 64 Polish higher education institutions, who attended regular and extra-mural studies. ${ }^{7}$ The research focused on a few areas: the experiences of distance education, the distance education environment, how students function in the physical, psychological and social dimensions, the substantive and organisational aspects of distance education, the positive and negative aspects, as well as support and expectations. The survey involved students with special educational needs, not necessarily with a certified disability, registered in the contact bases of the Universities' student-support units, from whom the students received the link to the survey. As the survey was performed using the CAWI (Computer Assisted Web Interview) method, the Authors took care to ensure accessibility of the e-form to people with disabilities, in particular, to blind people (i.e., the form had to stand up to $\mathrm{WCAG}^{8}$ standards). The questionnaire consisted of closed-ended questions, multiple-choice questions, rating/Likert scale questions, and openended questions, enabling free comments from the respondent. The research group included 36 people with visual impairment and 25 people with hearing impairment, which made up accordingly $12.4 \%$ and $8.6 \%$ of all respondents, respectively. Due to the sample size, a more in-depth analysis is not possible. The aim of the article is only to reveal and describe the difficulties associated with distance learning. The discussed issues require further exploration, and the research should be perceived as an introduction to further insightful analyses.

\footnotetext{
According to the data from 2019, there were 1594 people with hearing impairment and 1799 with visual impairment studying at Polish universities [GUS 2020].

8 WCAG (Web Content Accessibility Guidelines) - a set of guidelines on the accessibility of electronic content, including Internet services, for people with various needs. The accessibility of electronic content means the degree at which it can be perceived, understood and browsed by all users, regardless of their characteristics and dysfunctions, and regardless of features of the software and devices they use [Marcinkowski, Marcinkowski 2012].
} 
The research results made it possible to formulate preliminary recommendations for verifying e-learning systems in higher education and adjusting the education to the needs and abilities of students with disabilities and special educational needs.

\section{RESEARCH RESULTS}

\section{The areas of technology and methodology associated with distance learning}

Students with sensory disabilities significantly differed in statistical terms from their colleagues in certain aspects associated with needs in technical and methodological areas. This difference can be related to the fact that hearing and visual impairments are the disabilities that are compensated by technology and specialist software to the greatest extent; thus, in this area, the needs of these two groups are the most demanding.

\section{Demand for devices}

Out of the group of 25 students with hearing disabilities, 24 claimed that they had no proper devices (computer, tablet, smartphone, or printer) or technical facilities (software, Internet connection, etc.) to begin learning online. In the case of the blind students and students with visual impairments, only 3 out of the 35 students had appropriate equipment at their disposal. Students with sensory disabilities said it was necessary to supply their households with proper facilities in order to be able to study at home. Most frequently, they referred to computer equipment, and more seldom proper software, peripheral devices (scanner, printer, headphones) or Internet connection.

Asked about their preferred devices for distance learning (smartphone, computer, tablet, laptop), students with hearing disabilities stated that they used smartphones for education purposes considerably less frequently than other groups, which is the opposite to students with other disabilities, who use smartphones for e-learning more often than other devices. This preference is because students with hearing impairments use mostly visual channels, which is much better when using devices with larger screens (e.g., a tablet or computer).

\section{Preferred forms of distance learning}

Students with sensory disabilities also differed from other groups of disabled students in terms of their preferred form of distance learning. The highest percentage of students with hearing impairment (11 out of 25) appreciate sharing 
learning materials electronically for self-study (e.g., scans, excerpts from books, articles, links to websites, etc.). In comparison, such materials are favoured only by 8 students (out of 36) with visual impairment. People with other disabilities pointed to this form as the preferred one less frequently. Other groups of students preferred different forms of e-learning (e.g., e-learning platforms, lecture recordings available on a YouTube channel, getting presentations in PowerPoint). They chose live e-lectures (in real-time, with the possibility of interacting and asking questions, through platforms such as MS Teams, Zoom, Google Meet, etc.) as the one with the great advantages over all other forms. About $65 \%$ of all respondents with various disabilities pointed to this form as the most effective. ${ }^{9}$

Differences between the groups of students with disabilities were also revealed in answers to the question about supporting classes with additional forms (e.g., messaging applications, online consultations, various types of games and education quizzes). Here, a distinct differentiation between the group of students with a hearing disability and a visual disability was noted. Messaging applications, as a form that supports distance education, was most frequently and most eagerly used by deaf or hard-of-hearing students (11 out of 25 preferred it). In contrast, blind and visually impaired students used them most rarely ( 7 people in the group of 36). An inverse relationship was observed for online consultations with teachers - 22 students with visual disabilities, but only 6 students with a hearing disability indicated this form as the most frequently and most eagerly used. This situation is undoubtedly caused by the preferred communication channel (visual and writing in the case of people with hearing impairment, aural for people with visual impairment). The surveyed students also felt that teachers very rarely offered other forms to support distance learning, like education quizzes (e.g., Kahoot), or the possibility of a telephone conversation.

\section{Evaluating online classes}

The students were also asked to compare the quality of distance and campus-based learning regarding forms of classes such as lectures, discussion classes, seminars, laboratories, etc. Students with disabilities generally prefer traditional in-person classes. As far as the quality of the in-person mode is concerned, they see the most significant difference in forms such as laboratories $(77 \%)$, practical training $(75 \%)$ and tutorials (71\%). Distance learning has the least effect on reduced quality in

\footnotetext{
9 The results referring to the whole sample group have been presented in percentage, whereas the results referring to students with sensory disabilities, due to the samples being small, have been presented in real numbers.
} 
the case of lectures $(37 \%$ of students expressed the opinion that lectures are carried out better on campus) and exams and tests (49\% preferred the in-person mode). Only in the case of seminars were clear differences between students with various disabilities revealed. Students with hearing impairment clearly preferred online seminars (10 out of 25 people), while for students with visual impairments, they were clearly the least favoured ( 2 out of 36 people). The latter group assessed campus-based seminars significantly higher (20 of 36 people).

\section{Adjusting classes to students' needs}

The students were also asked to evaluate how well online classes had been adjusted to the needs resulting from their disabilities. In the respondents' opinion, these classes were, to a greater or lesser extent, adjusted to the needs of $74 \%$ of them. The situation differs for those with sensor disabilities, almost half of whom stated that distance classes were not adjusted to their individual needs. They mostly referred to poor communication with teachers (12 out of 36 people with visual impairment and 14 of 25 people with hearing disability). Additionally, students with a hearing disability mentioned difficulties resulting from the lack of transcriptions, the need to use a sign language interpreter or being unable to lip read when the camera was off. Meanwhile, those with visual impairment noticed the poor adjustment of the materials presented by teachers as well as lack of or poor digital accessibility of distance learning systems, e.g., e-learning platforms, messaging applications, etc.

\section{Negative and positive aspects of distance learning}

The negative consequences of moving to distance learning that students with disabilities indicated included isolation, the lack of social contacts and the possibility of making new social connections, meeting friends, or working on team projects. While other barriers enumerated included such problems as:

- Teachers shortening classes.

- Transferring all work onto students ("More time devoted to studying than at the University, Task development is very time-consuming, Covering much more material than during in-person classes").

- Being muted by other students or receiving offensive messages sent in a private chat ("More criticism from peers - instead of making fun during lecture, they were writing on the messaging app, much more - and their negative attitude was clearer").

- Problems with concentration during distance classes ("It is more difficult to listen to a teacher's monotonous voice while sitting at a computer"). 
- Lack of interpersonal contact; as a result, it is difficult to be motivated ("Lack of university atmosphere, Horrific desocialisation").

- Lack of skills to operate on such information channels ("The multitude of platforms used by teachers is confusing").

- Poor preparation of teachers for distance learning ("Knowing quite a number of methods for transferring knowledge, of course not to be applied in every area, I can see persistent digitalisation of the old-school way of teaching - the teacher and the audience of students. A lot of theory can be left for self-study, and the teacher could concentrate on advanced aspects during tutorials and laboratories. The e-trapez platform is a great example here").

- Lack of conditions for distance learning, and technical problems ("Lack of peace and quiet, Poor Internet connection").

- Lack of practical classes ("Laboratory classes run online will always have poorer quality than campus-based labs. Unfortunately, most of the issues presented in the practical part will not be well remembered by students").

It should be noted that isolation, the lack of social contact and the possibility of making new friends and hanging out with them, plus no real team projects are the most frequently mentioned negative consequences of transferring to the distance education mode. Interestingly, there is a statistically significant relationship between the type of disability and the deterioration of mental wellbeing. As far as the feeling of loneliness is concerned, there is a clear difference between students with visual impairment, out of which 27 people did not feel lonely, and other groups of people with disabilities, among which the feeling of loneliness was declared by more than half of the respondents. It seems that for blind people and people with visual impairments, social isolation may not be as problematic as for sighted people, who largely build their social relations on visual impressions and the body language of their interlocutors.

Another serious problem frequently mentioned by the respondents is health consequences - backache caused by being seated for long hours in front of a laptop or a computer, headaches or deteriorating eyesight. Such experiences may be encountered by all people who have worked and learned online, but they differently affect people with various types of disabilities. People with visual and hearing disabilities can be particularly exposed to negative consequences of many hours of sitting at a computer, because besides frequently occurring multiple disabilities (e.g., coupled with spine diseases), one of their senses is additionally overloaded (i.e., the one that compensates for their disability), which may lead to aggravation of impairment (e.g., eyesight deterioration in a visually impaired person) or the deterioration of a person's general psychophysical state. 
The students also noted the positive aspects of distance learning. They most frequently enumerated reduced expenditures associated with studying, saving time spent getting to university, improved family relationships, peace, comfort and a feeling of security at home, being able to sleep long enough and reconciling household duties with studies, better accessibility of reference materials and being able to read them back later on, less stress, and more engagement and assistance from teachers. The students also appreciate the possibility to "attend classes while in bed" or to "have more options of cheating on tests and exams".

\section{The social and psychological areas associated with distance learning}

When evaluating the areas influenced by the pandemic and by the need for distance learning, the socio-psychological sphere was the one marked by a predominantly harmful influence. A negative answer was most frequently chosen for all aspects, except for family relationships. For mental well-being, the percentage of negative responses was $36 \%$, for relationships with peers, it was $35 \%$, for mental health and everyday functioning $-33 \%$ each, and for physical health $-31 \%$. As many as $21 \%$ of respondents chose the response "very negative" to the question about the influence on mental health. The positive influence of the pandemic on family relationships was indicated by the highest percentage of respondents (34\%). The results were similar for students with sensory disabilities.

Slightly more than half of the respondents with visual and hearing impairment declared that they had received support from the university during distance learning. Students with sensory disabilities claimed that they used the following forms of support most frequently: adapted teaching materials (18 out of 36 people with visual impairment and 12 out of 25 people with hearing disability), IT support ( 9 out of 36 people with visual impairment and 6 out of 25 people with hearing disability), and psychological help (8 out of 36 people with visual impairment and 5 out of 25 people with hearing disability). Seven people referred to other types of support that they had received, e.g., financial support, the assistance of a university unit that supports students with disabilities, help in successfully applying for Individual Organisation of Studies, and extra consultations. Five students received support in the form of equipment for distance learning. However, at the same time, the other half of the surveyed students did not benefit from this type of support. The most frequently enumerated reasons include the lack of need for support, a lack of knowledge 
or information about the offered support, and a lack of support for students with disabilities from the university.

The students were also asked about the expected support that the University could offer them to prevent them from being excluded from education in the future in the case of distance learning. The largest percentage of respondents (24\%) had no opinion; they could not determine their needs or expectations concerning university assistance. The next largest group (16\%) comprised students who declared that they needed no assistance. Meanwhile, $12 \%$ expected financial support to buy devices for learning and to cover other costs of education. It is worth noticing a frequently mentioned need for psychological help (17\%), which is associated with the significant deterioration of mental functioning and the negative influence of social distancing and isolation declared by most of the surveyed students. In addition to the aforementioned issues, the students with sensory disabilities proposed fuller and longer access to reference materials (lectures, exercises, lecture notes, etc.), e.g., archiving such materials to be available later. The students also expect facilitation of the information flow between the university and the learners, planning classes in advance (12 votes), increasing the number of hours for individual consultations, more accessibility time of teachers and their assistants, more didactic support (10), more understanding and tolerance on the part of teachers (10), as well as more immediate and current help in solving technical problems connected with distance learning (7).

\section{SUMMARY}

The above research revealed certain weaknesses of online education provided during the pandemic at Polish universities. ${ }^{10}$ Among students with disabilities who participate in online education, certain subgroups can be differentiated that have different attitudes to the use of modern technologies in education. Not everybody is enthusiastic about this process, and it turns out that fascination with modern technologies does not automatically mean an aversion to traditional teaching methods. Not only do the respondents have limited experience in e-learning, but they also do not expect to transition to this type of education. Students noticed barriers in online learning, especially for certain types of classes. The vast majority

10 Similar research in other countries also revealed the weaknesses of distance learning during the pandemic and other associated problems, cf. Bernard et al. [2021] and Meleo-Erwin et al. [2021]. However, it would require a cultural context to compare the data. 
of respondents found it difficult to participate in discussion classes, laboratories and internships Interestingly, nearly half of the students declared that conducting exams online was not an advantage for them. It can therefore be assumed that, although the "generation of the Internet natives" grew up in the world of the omnipresent Internet, traditional didactics is deeply rooted in them. It can also be assumed that for the respondents with disabilities, direct contact with the educator and being able to get a direct response to their needs and expectations is very important. The reasons can be found not only in their lack of experience in online education, but perhaps also in their social situation and, in a way, in being used to the ever-supportive presence of a parent, guardian, support teacher, etc.

The research results also allow conclusions to be drawn regarding online education methodology and organisation. Students with sight and hearing impairments preferred communication channels that were in line with their abilities and needs. For visually impaired people, difficulties occurred especially in activities carried out on educational platforms and/or teachers making materials unavailable to them. They emphasized the lack of accessibility or its limitations in online learning systems (for instance, educational platforms). On the other hand, students with hearing impairments had problems following classes, mainly in the case of synchronous classes carried out using, e.g., Microsoft Teams. The students felt that the lecturers very rarely offered other forms of supporting online learning or an alternative way to reach them, for example, a telephone conversation. They also noticed lecturers' recurring lack of skills and competencies in online teaching, mainly regarding organization (for example, excessive content and materials, synchronous classes without a camera, shortening classes).

The significant effects of e-learning were revealed in the socio-psychological area of student functioning. The respondents indicated both positive and negative consequences. The positive effects were seen mainly in relation to family relationships, saving time and money, as well as having a greater sense of comfort. On the other hand, the negative effects of online education were most often related to general malaise, friendships, mental health, and everyday functioning, as well as physical health. Students with sensory disabilities do not differ at this point from the whole sample. In all these aspects, the respondents noticed a deterioration regarding their functioning before the pandemic. However, it is difficult to clearly define whether these consequences result from the general situation caused by the pandemic, for instance, from the restrictions, prohibitions and orders concerning almost all spheres of human life, or whether they are closely related to online education, which is a consequence of the above. 
It should be noted, however, that the above-mentioned negative and positive effects affect almost all students, including those who are "able-bodied". The results that show the scale of mental symptoms is particularly alarming. People with disabilities strongly feel a sense of loneliness and isolation. It was especially visible in the case of students with hearing impairment, and least visible among students with visual impairment, probably because they build relationships involving no visual impressions, like body language, for example.

The results of the research relating to the support of the respondents in online education can be summarized with the conclusion that half of the surveyed students benefited from the support of their universities. Most often, support was provided by university units for students with disabilities, including the rector's plenipotentiaries for students with disabilities. Thus, not only is the need for such structures to operate visible, but in many cases, so is their effectiveness is. However, some of the students did not use this option. It can therefore be assumed that, especially in the case of students with sensory dysfunctions who require didactic materials to be adapted, this situation may lead to them abandoning their studies. However, this was not clearly confirmed in the research. It is also worth undertaking further research to show the reasons for not using the support.

Students who had to adapt quickly to the requirements related to online education were often unable to specify their expectations regarding this process. This shows that it is difficult to define one's needs. The expectations that the respondents clearly specified related mainly to psychological support. In recent years, there has been growing interest in this type of support among students, and many universities offer such a service. The forced isolation caused by the pandemic and the related limitations changed the image of everyday life; it has had an impact on mental health and leaves a group of people with the need for professional help. Although the percentage of students who expect this type of support is not very high, it can be assumed that these people will "drop out" or even be excluded from the higher education system without being supported.

The research does not answer all possible questions, but it can be perceived as an introduction to further exploration. It seems reasonable to develop a typology, which was not possible through this research. Quality-oriented research would enable a more in-depth analysis and reveal important details for formulating recommendations. 


\section{CONCLUSIONS}

In the literature on the subject, it is often said that e-learning is a way to maintain high-quality formal education at the tertiary level, especially with an increasing number of students. This form of learning also facilitates reaching environments that, for various reasons, have limited access to higher education, including people with disabilities. E-learning can also help people acquire the competencies necessary in the modern world. These arguments are convincing, but, as the results of the research show, access to online education by itself does not guarantee graduation and may even lead to the risk of exclusion. Therefore, changes that will prevent such situations in the future are necessary. After the pandemic, the academic world is likely to be different. The ongoing "emergency" education will likely lead to the verification of both traditional and online methods of academic education for all students.

Based on the conclusions mentioned above, the Authors formulated recommendations that can improve the situation of students with disabilities so as not to exclude them from participating in higher education, which has become the current reality:

- the virtualization of didactic and organizational processes in higher education requires the development of e-learning implementation models and the definition of online education standards;

- for effective and efficient e-learning, it is necessary to invest in financial, information, material and human resources (for example, training academic teaching staff). Proper training and efficient teaching of online classes require that the content, technologies, context and people, communication and behaviour be taken into account. For people with sensory disabilities, additional adjustments are needed;

- it is necessary to develop/adapt tools, methods, and means (for example, educational platforms) to the current requirements in accordance with accessibility standards.

- it is reasonable to promote good practices for creating and conducting classes adjusted to the abilities and needs of students with disabilities (especially sensory disabilities);

- it is necessary to continuously monitor the situation of students with disabilities, especially those with sensory disabilities, who are particularly at risk of exclusion from distance learning; additionally, effective modernisation of the education offer that takes into consideration special education needs is indispensable; 
- it is necessary to run further research that will consider the characteristics of the dysfunctions and the influence of other factors; thus, the above analysis should be seen as the introduction to further exploration.

\section{BIBLIOGRAPHY}

Bernard Alec, Sara Weiss, Moshiur Rahman, Sheryl S. Ulin, Clive D'Souza, Anah Salgat, Kate Panzer, Joshua D. Stein, Michelle A. Meade, Michael M. McKee, Joshua Ehrlich. 2021. "The impact of COVID-19 and pandemic mitigation measures on persons with sensory impairment”. American Journal of Ophthalmology https://doi.org/10.1016/j.ajo.2021.06.019.

Błeszyński Jacek. 2006. Alternatywne i wspomagajace metody komunikacji. Kraków: Impuls.

Czerwińska Kornelia. 2014. Uczeń z niepełnosprawnością wzroku we współczesnej przestrzeni edukacyjnej. In: Podmioty, środowiska i obszary edukacyjne. Wyzwania i zagrożenia połowy XXI wieku. M. Suświłło, Fechner N.A. (eds.), 229-243. Poznań: WSB Publishing House.

Czerwińska Kornelia. 2016. „Funkcjonowanie osoby stopniowo tracącej wzrok w przestrzeni edukacyjno-rehabilitacyjnej”. Forum Pedagogiczne 2016(1): 167-180.

Domagała-Zyśk Ewa. 2013. Wielojęzyczni. Studenci niestyszacy i słabostyszący w procesie uczenia się i nauczania języków obcych. Lublin: KUL Publishing House.

GUS. 2020. Szkolnictwo wyższe i jego finanse w 2019 roku. https://stat.gov.pl/obszary-tematyczne/ edukacja/edukacja/szkolnictwo-wyzsze-i-jego-finanse-w-2019-roku,2,16.html [access: 10.11.2020].

Klyszcz Lucjan. 2007. Niewidomi i stabowidzacy studenci uczelni wyższych w roku akademickim 2005/2006. Kraków: Fundacja Instytut Rozwoju Regionalnego.

Krakowiak Kazimiera. 2012. Dar języka. Podręcznik metodyki wychowania językowego dzieci i młodzieży z uszkodzeniami narzadu stuchu. Lublin: KUL Publishing House.

Marcinkowski Artur, Przemysław Marcinkowski. 2012. WCAG 2.0. Podręcznik dobrych praktyk. Warszawa: Fundacja Widzialni.

Meleo-Erwin Zoe, Betty Kollia, Joe Fera, Allyssa Jahren, Corey Basch. 2021. "Online support information for students with disabilities in colleges and universities during the COVID-19 pandemic". Disability and Health Journal 14 (2021)101013, DOI: 10.1016/j. dhjo.2020.101013.

Męcfal Sylwia, Adrianna Surmiak, Izabela Ślęzak. 2020. (editors of the volume). „Badania społeczne i humanistyczne w czasach pandemii - aspekty etyczno-metodologiczne. Dyskusja podczas „Spotkań Badaczek”. Przegląd Socjologiczny 69(3): 203-214.

Muller-Siekierska Diana. 2019. Style funkcjonowania młodych osób z uszkodzeniami stuchu w bliskich relacjach interpersonalnych. Łódź: Uniwersytet Łódzki Publishing House.

Richardson John T.E., Gary L. Long, Alan Woodley. 2004. "Students with an undisclosed hearing loss: A challenge for academic access, progress, and success?". Journal of Deaf Studies and Deaf Education 9(4): 427-440.

Rzepka Henryk. 2007. Studenci niewidomi i słabowidzacy - poradnik dla wyższych uczelni. Kraków: Fundacja Instytut Rozwoju Regionalnego.

Szacka Barbara. 2003. Wprowadzenie do socjologii. Warszawa: Oficyna Naukowa.

Taddei Arianna, Esmeralda Azahar López, Rebeca Abigail Recinos Reyes. 2021. "Children with hearing disabilities during the pandemic: Challenges and perspectives of inclusion". Education Sciences \& Society - Open Access 12(1), DOI: 10.3280/ess12021 oa11871. 
Anna Gutowska

Joanna Sztobryn-Giercuszkiewicz

\section{RYZYKO WYKLUCZENIA Z EDUKACJI OSÓB Z NIEPEENOSPRAWNOŚCIAMI SENSORYCZNYMI JAKO KONSEKWENCJA PANDEMII COVID-19}

\section{Streszczenie}

W artykule autorki podejmują kwestię ryzyka „wypadania” z systemu szkolnictwa wyższego osób z niepełnosprawnościami sensorycznymi jako konsekwencję zmiany sposobu edukacji na kształcenie zdalne, w wyniku pandemii COVID-19. Prezentują informacje dotyczące specyfiki studentów z dysfunkcjami sensorycznymi, odnoszą się do problematyki kształcenia zdalnego na poziomie wyższym oraz przedstawiają założenia metodologiczne badań własnych. Wyniki przeprowadzonych badań oraz obserwacje wynikające z praktycznych doświadczeń autorek pozwoliły na sformułowanie wniosków odnoszących się do różnych obszarów związanych ze studiowaniem zdalnym, w tym $\mathrm{m}$. in. techniczno-metodycznego, społeczno-psychologicznego, potrzeb sprzętowych, oceny edukacji zdalnej, jej negatywnych i pozytywnych aspektów. Pozwoliło to na odsłonięcie pewnych aspektów edukacji zdalnej osób z niepełnosprawnościami, które wiążą się z koniecznością dalszej eksploracji poruszanej problematyki zarówno w wymiarze teoretycznym, empirycznym, jak i praktycznym.

Słowa kluczowe: studenci, niepełnosprawność sensoryczna, edukacja zdalna, pandemia COVID-19 